\title{
Planned relocation in Peru: advancing from well-meant legislation to good practice
}

\author{
Jonas Bergmann ${ }^{1}$ (D) \\ Accepted: 22 April 2021 / Published online: 24 May 2021 \\ (C) The Author(s) 2021
}

\begin{abstract}
Along Peru's rainforest rivers, rising flood extremes are increasingly exceeding coping capacities of vulnerable households. Peru has detailed legislation that embraces planned relocation as a strategic solution to such situations and various relocation projects are underway across the country. This research brief analyzes well-being consequences for two communities requesting relocation, using qualitative data collected from experts and 30 affected people. Initial results emphasize that weak governance, poverty, third-party involvement, and community action have influenced relocation outcomes. Delays and fragmented implementation have threatened people's well-being. One community, waiting for land to relocate since 2015, has suffered from continued hazard exposure, deteriorated material conditions, and reduced subjective well-being. The second community achieved relocation only after a decade in detrimental limbo. Although livelihood challenges persist, its inhabitants now benefit from better market access and decreased exposure, leading to higher subjective well-being. With rising needs for relocation worldwide, the cases highlight that detailed legislation is not sufficient to safeguard people's well-being. Advancing from wellmeant legislation to good practice requires adequate institutional capacity, effective mechanisms for oversight and accountability, better engagement of third parties, and dedicated efforts to strengthen community agency.
\end{abstract}

Keywords Planned relocation $\cdot$ Resettlement $\cdot$ Well-being $\cdot$ Climate change $\cdot$ Floods $\cdot$ Peru

\section{Introduction}

Peru, with its narrow desert coast, imposing highlands, and vast rainforest plains, features most of earth's climate zones and is highly vulnerable to climate change (MINAM 2016; ND-GAIN 2020). Already today, one in three inhabitants is exposed to hazards (SINAGERD et al. 2014). In Peru's Amazon rainforest specifically_which comprises $58 \%$ of its landmass and is home to $14 \%$ of the population (INEI 2018) - hazard incidence is high and has been exacerbated by more unpredictable and erratic rainfall seasons (Langill 2018; Zavaleta et al. 2018). People are familiar with annual flood cycles (Sherman et al. 2015; Takasaki et al. 1999); however, periodically, heavier rainfall can drive exceptionally high or long floods that pose existential threats (Coomes et al. 2010; List 2016; Sherman et al. 2016).

Jonas Bergmann

jonasber@pik-potsdam.de

$1 \quad$ Potsdam Institute for Climate Impact Research (PIK), Telegrafenberg A 31, 14473 Potsdam, Germany
While affected people dispose of strategies to deal with such hazards where they live, some floods exceed local capacities and periodically drive migration (Coomes et al. 2010; Hofmeijer et al. 2013; Langill 2018; List 2016; MIMP and IOM 2015; Sherman et al. 2016). When habitability is threatened, the state has occasionally relocated communities. While relocations can improve human security (Ferris and Weerasinghe 2020), past examples in Peru frequently harmed livelihoods and threatened well-being (cf. review in Bergmann et al. 2021). Planners often paid insufficient attention to social, cultural, and land issues; to infrastructure, livelihood, and transportation necessities; and to people's place attachment. Many of those affected declined to move, returned, or maintained dual residencies. Other relocations in South America and worldwide have implied similar challenges (Arnall 2019; Correa 2011; de Sherbinin et al. 2011).

These cautionary tales matter because rising climate risks will threaten the habitability of entire areas in Peru and may make more relocations necessary. In its rainforest, extreme floods have already increased (Barichivich et al. 2018; Gloor et al. 2013; Marengo and Espinoza 2016) and are projected to rise further due to climate change (Duffy et al. 2015; 
Langerwisch et al. 2013; Zulkafli et al. 2016). Extreme heat stress combined with the risk of an Amazon dieback could further threaten habitability over the long term (Borma et al. 2013; Masson-Delmotte et al. 2018). In other areas of Peru, more frequent extreme El Niño events, desertification, and severe glacier loss also threaten habitability (Bergmann et al. 2021).

Despite conflicted past use, global "momentum is shifting towards planned relocation" (Farbotko et al. 2020), and Peru has embraced it as a strategic solution in various frameworks (French et al. 2020; Lavell et al. 2016). Two subnational climate strategies consider relocation a priority action, ${ }^{1}$ and in 2012 , Peru adopted a law on relocation from areas with "very high, unmitigable risk," one of the rare existing examples worldwide. ${ }^{2}$ The law's regulation $^{3}$ details the full relocation process and covers most categories recommended by international guidance (Fig. 1) from planning, participation, transfer, and livelihood restoration to monitoring and evaluation. Given past challenges in relocations, widespread ambitions for their use, and possibly rising future needs, analyzing how words are put into action in Peru promises insights for stakeholders in and outside of the country.

This research brief presents preliminary lessons on good practices and well-being risks observed in two relocations in the Peruvian rainforest. There is no universally accepted definition of what "being well" encompasses (Dodge et al. 2012; Gasper 2007). In this research brief, well-being is framed as arising from chances to meet human needs, how needs are met, and how people perceive need fulfillment (Costanza et al. 2007). The applied framework ${ }^{4}$ covers material, relation$\mathrm{al}$, and subjective dimensions as key pillars of well-being (Gough 2008; White 2010).

Through this lens, the investigated cases demonstrate that the road from well-meant legislation to good practice and improved well-being is still rocky in Peru. Results emphasize the critical roles of governance, resource availability and livelihood restoration, third-party engagement, and community action in shaping relocations and well-being.

\footnotetext{
${ }^{1}$ Estrategia regional frente al cambio climático Cusco (Regional Strategy against Climate Change, 2012); Actualización de la estrategia regional de cambio climático Junín (Update of the Regional Climate Change Strategy Junín 2019).

${ }^{2}$ Ley N²9869 (Law, 2012); Ley N³0645 (Modification, 2017).

${ }^{3}$ Decreto Supremo N¹15-2013-PCM (Regulation, 2013).

${ }^{4}$ Needs of interest were identified in a substantive good list approach (Parfit (1992)), based on emic research among Peruvians (Copestake (2008, 2011)). Needs covered the main areas development from a secure base; a space to live better; and social relatedness. Drawing on psychological research, perception of need fulfillment was conceptualized as life satisfaction, emotional balance (Diener and Tay (2016)), and future expectations (Gulyas (2015)).
}

\section{Methods and data}

Findings are based on thematic and evaluative analyses (Kuckartz and Rädiker 2019) of problem-centered interviews (Witzel and Reiter 2012) with 30 affected people from two villages in the Peruvian department San Martín (Fig. 2), recruited using theoretical sampling in 2019. Respondents $(14 \mathrm{~m} / 16 \mathrm{f})$ were between 22 and 62 years old and mostly smallholder, subsistence farmers, and day laborers with complementary reliance on forest and river products (Table 1), as seen in other Peruvian rainforest areas (Coomes et al. 2010; Sherman et al. 2016; Zavaleta et al. 2018). Women often helped with labor, raised free-range animals, and worked in housekeeping. Additional interviews were conducted with experts at national, regional, and local authorities overseeing relocations, ${ }^{5}$ as well as mayors, religious leaders, and health post workers in the visited communities.

\section{Next research phase}

The case studies form part of a monograph (Bergmann in preparation). Next steps for the two rainforest case studies include in-detail analyses of all objective and subjective dimensions of well-being described in the conceptual framework as well as their generative mechanisms. The findings will feed into a comparative analysis of how and why various forms of migration from climate-affected zones across Peru's rainforest, highlands, and coastal area influence well-being.

\section{Results and discussion}

\section{Case study context}

V1, the first studied village, has a population of approximately 150 farmers who auto-identify as mestizos (Amerindian and other ancestry), while V2 is significantly larger with 700 indigenas (indigenous people) (INEI 2018). Poverty is severe. According to government data, $42 \%$ and $55 \%$ of habitants in the two districts ${ }^{6}$ where $\mathrm{V} 1$ and $\mathrm{V} 2$ are located, respectively, are poor (extremely poor: $13 \%$ and 26\%) (MIDIS 2020). District-level data show that $57 \%$ and $65 \%$ of households,

\footnotetext{
${ }^{5}$ National-level interviews included staff at the Ministry of Housing, Sanitation and Construction (MVCS) and the National Center for the Estimation, Prevention and Reduction of Disaster Risk (CENEPRED). At the subnational level, interviews comprised staff at San Martín's Regional Office for Security and National Defense and its staff at provincial and district levels, as well as at the Regional Environmental Authority (ARA), its Executive Directorate of Territorial Management, and its Technical Group on Climate Change.

${ }^{6}$ More granular data is unavailable. In the district where the indigenas live, there are 47 other villages and 4 urban areas. In the district containing the mestizo community, there are 34 other villages and 4 urban areas.
} 


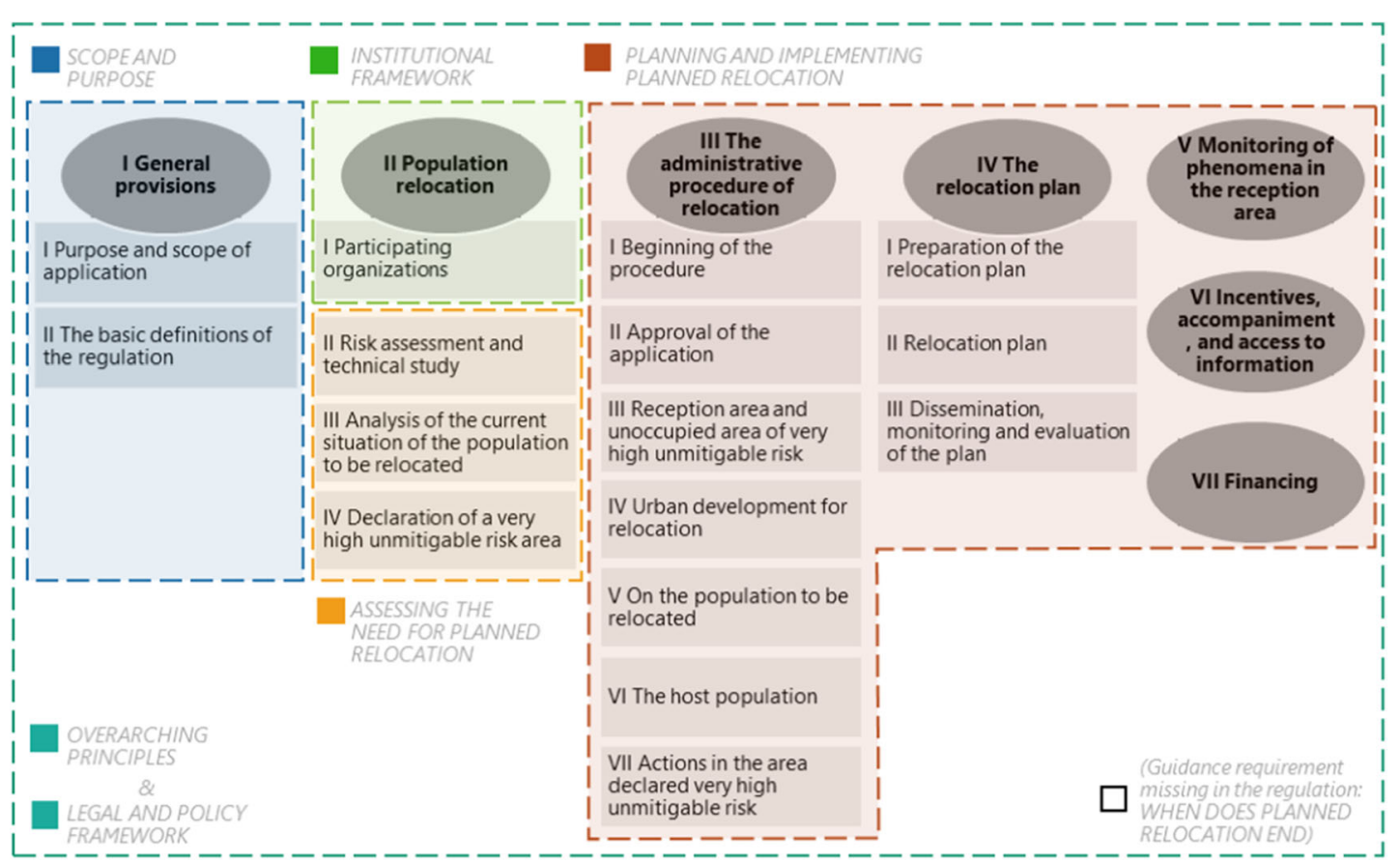

Legend: Chapter in Peruvian Regulation Subchapter in Peruvian Regulation

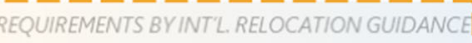

Fig. 1 Overview of provisions in the Peruvian relocation regulation, compared to elements recommended by the Guidance on Planned Relocation (Brookings et al. 2015). Note: Produced and translated from Spanish by the author

respectively, have only dirt floors, and many use fragile housing materials (INEI 2018) (Fig. 3 shows housing in V1 and V2). Close to $80 \%$ of all households cook with wood. In both districts, more than $60 \%$ of people have only primary education or less, and around 15\% cannot read and write. Within rural Amazonian communities, intersectional factors usually heighten vulnerabilities (Hofmeijer et al. 2013; Langill 2018; Takasaki et al. 2010). For example, women face higher risks of mental illness after floods (Rojas-Medina et al. 2008). Nonmajority ethnic groups frequently face discrimination (Barrón 2008) and disproportionately high poverty incidence (INEI 2016), as observed for indigenas in V2.

While multiple hazards threaten the villages (Fig. 4), floods from adjacent rivers are most damaging. V1 suffered from single, large floods in 1963 and in 1999. Major floods inundated V2 in 1977 and 2015, and additional low floods occur every year. Due to these repeated floods - and authorities' claim of a lack of physical protection options - the mestizos and indigenas requested relocation in 1999 and 2015, respectively. Risk appraisal, fear and uncertainty, deprivations, and children's future prospects drove their decisions, along similar lines as in other cases (Seebauer and Winkler 2020b). The state declared both zones as areas of "very high, unmitigable risk" in line with Peruvian legislation, although the law's exact threshold of "unmitigable" hazards remains ambiguous (Venkateswaran et al. 2017). While both communities decided themselves to relocate-often a catalyst for success
(Matthews and Potts 2018) — only V1 relocated in 2014, after struggling for 15 years to find land themselves, whereas V2 has remained in limbo since 2015. Length of relocation processes shapes well-being trajectories (Thaler et al. 2020), and the preliminary analysis below identifies further mechanisms in these two cases.

\section{Mechanisms influencing well-being}

Governance is the first key factor that influenced relocations and well-being. Relocations have complex, cross-cutting governance demands (de Sherbinin et al. 2011). In Peru, as in other countries, weak governance structures, and institutional constraints - including lack of participation and interministerial coordination, technical expertise, institutional leadership, and organizational and technical capacities - can deteriorate results (Bronen and Chapin 2013; Connell and Coelho 2018). Both investigated communities self-initiated relocation but struggled to receive sustained support from regional authorities, who perceived a low benefit-cost ratio for action, as witnessed in other relocations that address small and marginalized shares of the electorate (Hino et al. 2017). In both investigated cases, local authorities lacked capacities to prepare adequate relocation plans and advance relocations in a timely manner. There were also insufficient resources for legally required monitoring and evaluation. 
Table 1 Basic data on interviewees from relocation sites

\begin{tabular}{|c|c|c|c|c|}
\hline Alias & Gender & Age & Main occupation & Secondary occupation \\
\hline \multicolumn{5}{|c|}{ Mestizo community V1 } \\
\hline V1-1 & M & 54 & Day labor & - \\
\hline V1-2 & M & 61 & Day labor & Crops \\
\hline V1-3 & M & 43 & Providing services & Crops \\
\hline V1-4 & $\mathrm{F}$ & 47 & Housekeeping & Crops \\
\hline V1-5 & M & 59 & Providing services & Livestock farming \\
\hline V1-6 & M & 32 & Day labor & Crops \\
\hline V1-7 & $\mathrm{F}$ & 42 & Housekeeping & Crops \\
\hline V1-9 & $\mathrm{F}$ & 53 & Housekeeping & Crops \\
\hline V1-10 & M & 56 & Crops & Day labor \\
\hline V1-16 & $\mathrm{F}$ & 52 & Crops & Selling products \\
\hline V1-17 & $\mathrm{F}$ & 49 & Crops & Selling products \\
\hline V1-18 & $\mathrm{F}$ & 30 & Housekeeping & Crops \\
\hline V1-19 & M & 44 & Day labor & Crops \\
\hline V1-20 & M & 55 & Crops & - \\
\hline \multicolumn{5}{|c|}{ Indigenas community $\mathrm{V} 2$} \\
\hline V2-1 & $\mathrm{F}$ & 42 & Crops & Providing services \\
\hline V2-2 & M & 37 & Selling products & Providing services \\
\hline V2-3 & M & 39 & Selling products & Providing services \\
\hline V2-5 & $\mathrm{F}$ & 46 & Crops & Free-range animals \\
\hline V2-6 & M & 52 & Crops & Free-range animals \\
\hline V2-7 & $\mathrm{F}$ & 39 & Crops & Selling products \\
\hline V2-9 & M & 35 & Crops & Free-range animals \\
\hline $\mathrm{V} 2-10$ & $\mathrm{~F}$ & 30 & Crops & Selling products \\
\hline V2-11 & $\mathrm{F}$ & 62 & Crops & Free-range animals \\
\hline $\mathrm{V} 2-12$ & $\mathrm{~F}$ & 29 & Crops & Free-range animals \\
\hline V2-14 & $\mathrm{F}$ & 40 & Crops & Free-range animals \\
\hline $\mathrm{V} 2-15$ & M & 58 & Crops & Free-range animals \\
\hline V2-16 & $\mathrm{F}$ & 38 & Crops & Selling products \\
\hline V2-17 & $\mathrm{F}$ & 56 & Crops & - \\
\hline V2-18 & $\mathrm{F}$ & 67 & Crops & Fishing \\
\hline$V 2-19$ & M & 73 & Crops & Fishing \\
\hline
\end{tabular}

For V1, personal leadership of a governor helped start the relocation, as witnessed in other contexts (Mortreux et al. 2018; Sipe and Vella 2014). However, no assistance for finding land was provided, and promised support for reconstructing houses and improving infrastructure is pending. Since moving in 2014, the central state has still neither issued the final ministerial resolution to approve the request for relocation, nor permitted a land-use change from rural to urban; both steps are prerequisites for receiving property titles and thus access to social programs such as housing support (as envisaged by legislation). Interviewees, lacking the means to make their voices heard, felt "deceived" (V1-3) by the government and "as if this village would not exist" (V1-6). The impossibility to express individual needs (Thaler et al. 2020) and to participate meaningfully (Wilmsen and Webber 2015) are frequent challenges in relocations, often related to power hierarchies (Bertana 2020). As witnessed here, highly centralized decision-making (Perry and Lindell 1997) and disregard for rural development needs (Arnall 2019) often constitute challenges for sustaining relocations. Respondents observed a lack of political will, interest, and skilled personnel, rotating functionaries, and competing priorities of authorities in attending emergencies. Government inaction also seemed driven by a lack of accountability, including inadequate institutional structures and remit, as well as the lack of pressure to respond to hazards, to establish legitimacy, or to reap adaptation benefits, similar as in other relocations (Mortreux et al. 2018).

Indigenas in V2 experienced comparable inaction. The regional government promised the major share of funds for acquiring land for the relocation in 2015, but has not delivered, allegedly due to changing functionaries and priorities. Many respondents felt treated like in "a game" and had gotten angry because "it's been four years now and we have hardly advanced at all" (V2-2), while authorities "don't stop cheating us" (V2-14). Village authorities said the implementation of their legally guaranteed participation rights has been insufficient. They have lacked access to decision-makers and traveling regularly to the capital to make their case is prohibitively expensive. Government inaction has increased vulnerabilities of at-risk groups: After declaring the original settlement uninhabitable in 2017, authorities stopped promised investments in education, health, sanitation, and water. Such service discontinuation often causes marginalization in relocations (Cernea 2004). Experiencing these governance problems, many interviewees worried that even if they moved eventually, they would not receive promised access to social programs needed for reconstruction. A few attached hopes to a recent change of functionaries at district and regional levels.

Besides governance, poverty has constituted the second hurdle for success, confirming inverse correlations between vulnerability, migration, and outcomes found in other settings (Adger et al. 2014; Black et al. 2013; Warner and Afifi 2014). While the state lacked incentives to deliver solutions, V1 and V2 had no proper resources to act on their own, as witnessed in other cases (Hino et al. 2017). Land has been a key obstacle, as frequent in relocations (Piggott-McKellar et al. 2019). Without state funding - and the government failing to exploit all legal options, such as using charges from natural resource exploitation and mining - the poor mestizos struggled for over ten years to acquire the small patch of needed land privately. During this time, they suffered from continued hazard exposure, high uncertainty, and mental health burdens. After moving, poor households had to reconstruct their houses piece by piece and without legally promoted state support. Years later, "All we have, what little we have, is thanks to ourselves" (V13). While villagers have improved houses, various homes are still provisional and sanitation is missing, which causes hardship for older adults, children, sick or disabled persons, and 


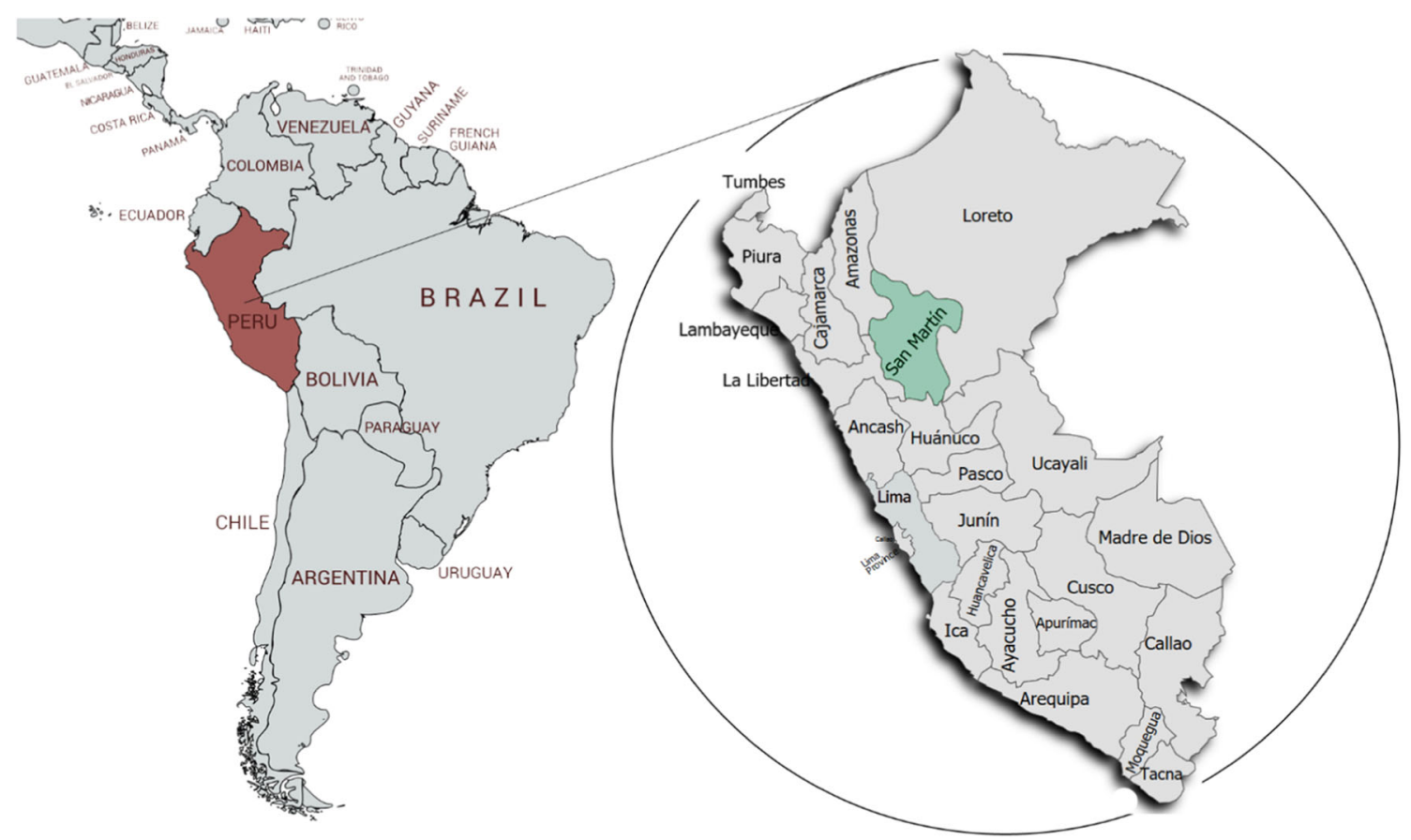

Fig. 2 Location of Peru in South America (left) and the rainforest region San Martín in Peru, home to the two investigated communities (right). Note: To safeguard the anonymity of respondents, exact relocation sites

pregnant women. The 700 indigenas require more land to relocate than the 150 mestizo farmers. They have waited for promised supported acquisition since 2015 and, being extremely poor, cannot step in to buy their own land. Floodinduced losses have continued and, combined with service discontinuation, prompted downward spirals of poverty. Various villagers felt "scared" (V2-18) since "you do not know the amount of water that comes, well, how can you not be afraid?" (V2-10). Households have minimal space for economic maneuver; they fear the costs of a possible future rebuilding and having to trade-off priorities (for example, investments in protection measures versus money needed for children's education). With growing delays, some have started are not displayed. Maps created by the author, based on the tools paintmaps.com $\odot$ and mapchart.net $(\subset$

to invest hard-won money in basic physical protection, which increases attachment to dangerous flood zones and consumes scarce resources needed for potential future rebuilding.

Third, a "complex network of agents" beyond the state influences relocations (Rogers and Wilmsen 2019), an aspect still under-researched. Here, private actors were key for land and reconstruction issues. Because the state did not provide land for the relocation of V1, the villagers eventually swapped territories with a local agribusiness. In another lucky coincidence, a local canalization enterprise gave them access to jobs, and the income permitted farmers to slowly rebuild houses even without legally promoted state support. Without these two private entities, relocation and reconstruction would have
Fig. 3 Decaying houses in abandoned site of V1 (top left) and homes still under construction in relocation site (top right); house in V2 in the stalled relocation (bottom left), directly by a river (bottom right). Note: Photos by the author

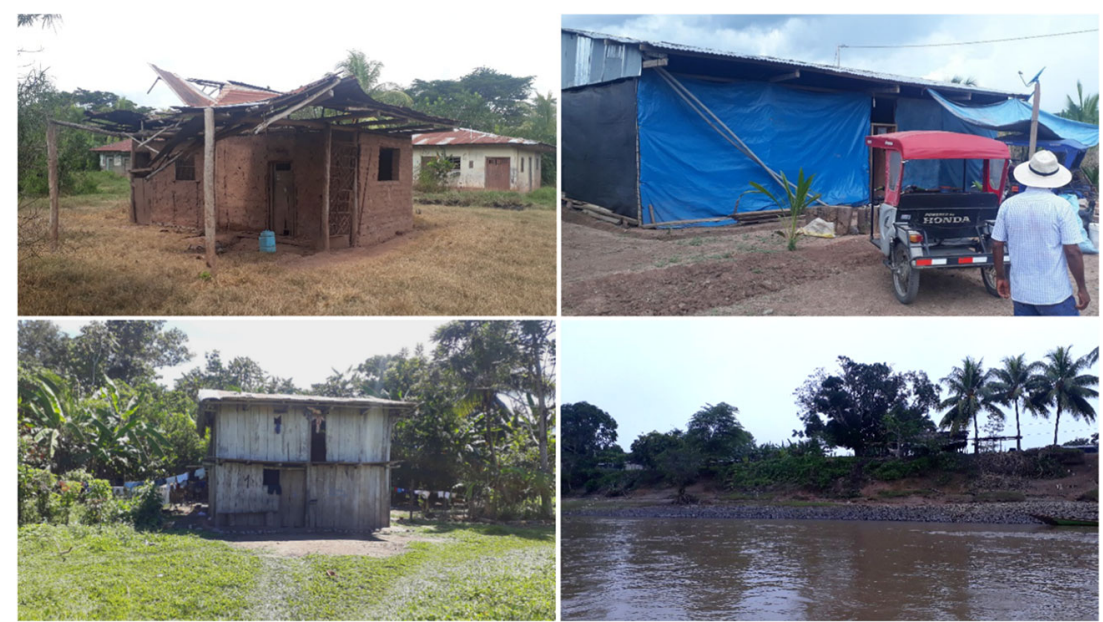


Fig. 4 Hazards affecting interviewees from V1 and V2. Note: Percentage of interviewees who mentioned hazards affected them at least once. Produced by the author

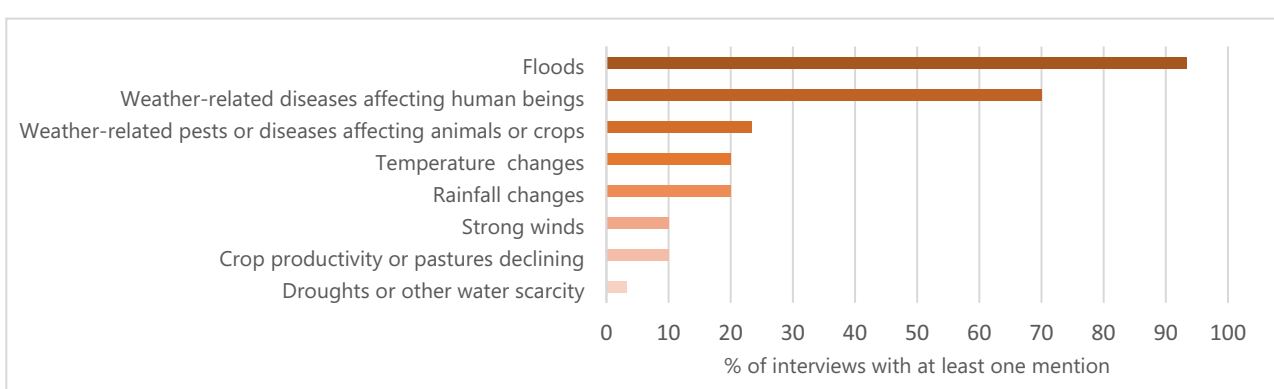

failed. Yet, private actors can also create obstacles: The owner of the most fitting destination territory for the relocation of V2 allegedly inflated prices above market standards to exploit the opportunity for government money, emphasizing the centrality of land in relocations (Georgetown University et al. 2017). Regional authorities could have intervened but have not adopted the suggestion by technical experts to expropriate with compensation at real costs, as permitted by law, leaving the indigenas in limbo.

Livelihood restoration is a fourth key condition for success (Brookings et al. 2015; Cernea 2004). Farmers in V1 emphasized better livelihood options as the major improvement after relocation: Their new, nearby site is closer to a street, which makes it easier to sell products, get hired for day labor, and travel for education and health. Still, relocation planners paid limited attention to people's lifestyles: the newly designated, smaller lots complicated traditional activities like raising freerange animals. Similarly, indigenas doubted that new lots would be appropriate. Yet, hopes prevailed that the envisaged land, around one kilometer away and close to a planned road, would facilitate better access to markets and technology (whereas the village is currently only accessible by boat). The new location would also be close to farmers' fields, facilitating the continuation of essential livelihoods. Overall, many villagers retained hope that relocation would improve their livelihoods and result in a new "modern village" (V2-2) with better housing and infrastructure shielded from hazards, buying into a common modernization narrative known from other contexts (Arnall 2019). Global studies, however, caution about impoverishment risks in relocations (Wilmsen and Webber 2015); many at best improve infrastructure and goods but threaten natural, social, financial, human, and cultural capitals (Piggott-McKellar et al. 2019).

People's agency has been a fifth factor for success, an element still under-researched (McMichael et al. 2019). Mutual support systems like food sharing have mitigated flood damages in both communities, as frequently seen immediately after disasters (Braun and Aßheuer 2011; Drury and Cocking 2007). Yet, in V1, agency extended beyond the crisis moment; interviewees said they have fought "with the sweat of our forehead" (V1-3) to make the relocation happen and to avoid some of the severest risks. Foremost, they became the driving force behind relocation through their own efforts to find land. Farmers also staged demonstrations to express disappointment with initially missing infrastructure and services, pointing to the importance of resistance (McMichael et al. 2019). With limited state support, men and women worked for free in community tasks like earthworks and rebuilding the church. The case shows that communities can be agents advancing their own relocations despite government inaction (Iuchi 2014); even when incentives for implementing actors to conduct relocations appropriately are low, bottom-up fights and strong community organization can result in reasonable outcomes (Hino et al. 2017). This is not always the case, however; while indigenas have also used mutual assistance systems after floods, and stood united in their fight for relocation, their means have not always been helpful. For example, frustrated villagers refused to let go of state representatives after a meeting, attempting to press the regional governor to fulfil long-standing promises. The act of resistance, which the state perceived as hostage taking, hardened lines. Meanwhile, the extremely poor farmers have remained unable to exchange or purchase land on their own, illustrating that structural constraints can strongly reduce agency and thus influence (im)mobility (de Haas 2014) and well-being.

\section{Well-being dynamics}

Well-being trajectories among relocatees develop over time and hinge on life circumstances as well as chosen coping strategies (Seebauer and Winkler 2020a). Mestizo villagers faced significant hurdles in the relocation process, and especially at-risk groups suffered psychosocial stress in the drawnout transition, as seen elsewhere (Cernea 2004). Despite persistent challenges after relocating, many farmers followed a trajectory of "delayed recovery" (Seebauer and Winkler 2020a): Although most were still "just surviving" with their income (V1-3), almost all considered their eventual relocation as successful in material dimensions, owing to decreased exposure and better market access. Regarding subjective wellbeing, most respondents reported less anxiety, more happiness, more life satisfaction, and positive outlooks to the future, 
especially for their children. Two respondents felt "happier, now that there is more work" (V3-17) and explained that "here, we no longer have any fear" (V3-18). Conversely, most indigenas were on a trajectory of "chronic distress" (Seebauer and Winkler 2020a) due to the stalled relocation; many felt "discouraged" (V2-10) and like "going in circles, you are trapped" (V2-3). Need fulfillment has deteriorated due to continued flood damages and premature service discontinuation. Most respondents felt less satisfied with life, sad, angry, or helpless, and expressed fear of future disasters. Two interviewees worried that the "river cannot be trusted, that one, any time it can take you" (V2-9) and that "every time it floods, we suffer the same, there is no change. Change can happen when we leave from here, when they relocate us" (V2-14). Families longed for a safer future for their children, but years of weak governance have raised doubt. In summary, preliminary analysis suggests that the state approached both relocations "as a mechanical process" with limited attention to people's well-being (Perry and Lindell 1997).

\section{Lessons learned and recommendations}

Peruvian communities will face increasing climate risks. Because tens of thousands of people live in high-risk zones, relocation is neither sensible nor feasible for all (Bergmann et al. 2021). The state should enforce zoning properly to avoid new settlements in such areas. Simultaneously, it should clarify legal ambiguities of what makes risks "unmitigable" for existing settlements (Venkateswaran et al. 2017), and ensure the exhaustion of softer options for risk reduction and climate adaptation (French et al. 2020), as instructed by law. Authorities should strengthen the participative process that must preside the decision to move and duly explore alternative options. Once moving becomes necessary, Peru's relocation legislation constitutes progress, but the two cases analyzed here illustrate that implementation remains fragmented. Other studies confirm this implementation gap between policy and practice in Peru's disaster risk reduction and management strategies (French et al. 2020; French and Mechler 2017; GFDRR 2010), echoing Peru's general governance challenges (McNulty and Guerra Garcia 2019; Morón and Sanborn 2006; Thiery 2016). The recommendations below could help communities, authorities, and other concerned actors bridge identified gaps:

\section{Improving governance to put people's well-being first}

Local authorities are to prepare the relocation plans but often lack capacities. The central government should provide resources to translate national frameworks into local practice, for example, by investing in technical and absorption capacities of subnational authorities in strongly affected areas, alongside technical support from national- level experts. Transition protocols to mitigate staff rotation could help sustain relocations. Beyond access to information, consultation and effective participation must be strengthened throughout relocation and in legislation, which enshrines these rights ambiguously. ${ }^{7}$ To bridge funding gaps, the state could better exploit the legally permitted option of using charges from natural resource exploitation and mining. Efforts are also needed to alleviate public investment gaps between declarations of uninhabitability and settlements' eventual relocation. To address land scarcity issues and to avoid price hikes, the state should explore the legally permissible tool of expropriation with adequate compensation. Legislation entitles relocatees to benefits and rights throughout the process; the Ministry of "Vulnerable Populations and Women" (MIMP) should receive adequate funding to fulfil its legal task to protect and assist them, with special attention to atrisk groups. The state should invest more in co-designing relocation sites, long-term livelihood restoration, and dignified living conditions in accordance with people's customs and culture, as legally guaranteed. Ensuring proximity to accessible livelihood options, transportation, and markets is key. Swifter granting of individual titles is needed so people can receive the access to social programs that legislation encourages, including social housing and reconstruction support. Moreover, the state should warrant the legally required collection of disaggregated baseline and follow-up data, which is essential for institutional learning and for guaranteeing people's rights and wellbeing.Finally, oversight and accountability must improve. Relocatees cited numerous grievances, complaints, and conflicts, but the state did not seem to fulfil its obligation to inform them about legally required resolution mechanisms (including mediation and arbitration by designated government entities), rendering these mechanisms inaccessible.

\section{Catalyzing third-party engagement}

Government accountability could also profit from the engagement of third parties, like the Peruvian Ombudsman, non-governmental organizations, and the media. For example, advocacy organizations with campaigning experience in development-induced resettlement could integrate disaster relocation in their portfolios, and international protective accompaniment could help defend people's rights. Private sector engagement is also key for success. Authorities could encourage landowners to consider synergetic options with communities wishing to relocate,

\footnotetext{
${ }^{7}$ Peru's relocation law makes citizen participation a right but only "when circumstances allow" and "with the necessary availability" (art. 5, 6, 17, translated by the author).
} 
such as swapping territories or trading land for labor. Moreover, they could encourage private companies to bring forward planned investments in destination areas and give preferential access to relocatees, creating income for recovery. Likewise, promoting contributions to relocation costs from the local private sector could be beneficial, for example, through solidarity funds, materials, or micro-credit programs.

\section{Strengthening community agency}

States must be held accountable to fulfill their obligations to respect, protect, and fulfill human rights of relocatees. However, given frequent lack of political will and limited state capacities, the international community should also invest in affected communities' capacity to speak and act for themselves. For example, climate adaptation funding could finance community organization-building, negotiation training for local leaders, and travels to cities where administrations reside so they can make their voices heard. Supporting citizens' campaigning skills could be another important avenue. For example, affected communities could receive media training and access to social media and watchdog networks. Projects could sponsor exchange between affected communities to promote peer-to-peer sharing of experiences in relocations and alliance-building. Finally, empowerment projects could foster more horizontal relationships with the state, for example, by integrating traditional knowledge in collaborative risk monitoring and assessment, or by nurturing community-based self-reliance strategies throughout relocation (Bronen et al. 2020; Chapin et al. 2016).

\section{Conclusion}

Technical experts estimate that at least 15 relocations are underway in Peru. More communities may require relocation soon, especially those located by rainforest rivers, where climate change will increase flood risks and physical protection options can be limited. To safeguard people's well-being and rights, bridging the gaps between Peru's detailed relocation legislation and its implementation will be key and could provide pioneering lessons to other countries seeking to regulate and conduct relocations. This investigation highlights the importance of institutional (dis-)incentives that influence relocation governance and the well-being risks emerging from delayed and fragmented processes. It emphasizes the need for strong non-state actors and civil society to act as checks and balances and simultaneously demonstrates that bottom-up community action can improve outcomes. For the future, more research is warranted on complex networks of actors involved in relocations, affected people's agency, and mechanisms shaping both subjective and objective wellbeing over extended timeframes.

Acknowledgments The author wishes to thank Oscar Aguirre Gonzalo, Elena Correa, Elizabeth Ferris, Emanuela Paoletti, and three anonymous reviewers for their valuable comments on earlier drafts.

Funding Open Access funding enabled and organized by Projekt DEAL. This publication was made possible through the support provided by the East Africa-Peru-India Climate Capacities (EPICC) Project. The Potsdam Institute for Climate Impact Research leads the execution of the project with its partners, The Energy and Resources Institute and the Deutscher Wetterdienst (the German Meteorological Service). EPICC is part of the International Climate Initiative. The Federal Ministry for the Environment, Nature Conservation and Nuclear Safety supports this initiative on the basis of a decision adopted by the German Bundestag.

Open Access This article is licensed under a Creative Commons Attribution 4.0 International License, which permits use, sharing, adaptation, distribution and reproduction in any medium or format, as long as you give appropriate credit to the original author(s) and the source, provide a link to the Creative Commons licence, and indicate if changes were made. The images or other third party material in this article are included in the article's Creative Commons licence, unless indicated otherwise in a credit line to the material. If material is not included in the article's Creative Commons licence and your intended use is not permitted by statutory regulation or exceeds the permitted use, you will need to obtain permission directly from the copyright holder. To view a copy of this licence, visit http://creativecommons.org/licenses/by/4.0/.

\section{References}

Adger WN, Pulhin JM, Barnett JR, Dabelko GD, Hovelsrud GK, Levy M, Oswald Spring U, Vogel CH (2014) Human security. In: Field CB, Barros VR, Dokken DJ, Mach KJ, Mastrandrea MD, Bilir TE, Chatterjee M, Ebi KL, Estrada YO, Genova RC, Girma B, Kissel ES, Levy AN, MacCracken S, Mastrandrea PR, White LL (eds) Climate Change 2014: impacts, adaptation, and vulnerability. Part A: Global and sectoral aspects. Contribution of Working Group II to the Fifth Assessment Report of the Intergovernmental Panel on Climate Change. Cambridge University Press, Cambridge, United Kingdom and New York, NY, USA, pp 755-791

Arnall A (2019) Resettlement as climate change adaptation: what can be learned from state-led relocation in rural Africa and Asia? Clim Dev 11:253-263. https://doi.org/10.1080/17565529.2018.1442799

Barichivich J, Gloor E, Peylin P, Brienen RJW, Schöngart J, Espinoza JC, Pattnayak KC (2018) Recent intensification of Amazon flooding extremes driven by strengthened Walker circulation. Sci Adv 4: eaat8785. https://doi.org/10.1126/sciadv.aat8785

Barrón M (2008) Exclusion and discrimination as sources of inter-ethnic inequality in Peru. Economia 61:51-80

Bergmann J, Vinke K, Fernandez Palomino C, Gornott C, Gleixner S, Laudien R, Lobanova A, Ludescher J, Schellnhuber HJ (2021) Assessing the Evidence: Climate Change and Migration in Peru. Potsdam Institute for Climate Impact Research (PIK); International Organisation for Migration (IOM), Potsdam and Geneva

Bergmann J (in preparation) Migrating from areas with climate hazards: Assessing multilayered well-being consequences across Peru. Doctoral thesis, Humboldt-Universität zu Berlin 
Bertana A (2020) The role of power in community participation: relocation as climate change adaptation in Fiji. Environ Plann C Polit Space 38:902-919. https://doi.org/10.1177/2399654420909394

Black R, Arnell NW, Adger WN, Thomas D, Geddes A (2013) Migration, immobility and displacement outcomes following extreme events. Environ Sci Pol 27:S32-S43. https://doi.org/10. 1016/j.envsci.2012.09.001

Borma LS, Nobre CA, Cardoso MF (2013) Response of the Amazon tropical forests to deforestation, climate, and extremes, and the occurrence of drought and fire. In: Pielke RA (ed) Climate vulnerability: understanding and addressing threats to essential resources: volume 2: vulnerability of human food resources to climate. Academic Press, Cambridge, pp 153-163

Braun B, Aßheuer T (2011) Floods in megacity environments: vulnerability and coping strategies of slum dwellers in Dhaka/Bangladesh. Nat Hazards 58:771-787. https://doi.org/10.1007/s11069-0119752-5

Bronen R, Chapin FS (2013) Adaptive governance and institutional strategies for climate-induced community relocations in Alaska. PNAS 110:9320-9325. https://doi.org/10.1073/pnas.1210508110

Bronen R, Pollock D, Overbeck J, Stevens D, Natali S, Maio C (2020) Usteq: integrating indigenous knowledge and social and physical sciences to coproduce knowledge and support community-based adaptation. Polar Geogr 43:188-205. https://doi.org/10.1080/ 1088937X.2019.1679271

Brookings, Georgetown University, UNHCR (2015) Guidance on protecting people from disasters and environmental change through planned relocation. http://www.unhcr.org/protection/environment/ 562f798d9/planned-relocation-guidance-october-2015.html. Accessed 9 August 2018

Cernea M (2004) Impoverishment Risks and Reconstruction: A Model for Population Displacement and Resettlement: Presented at UN Symposium on Hydropower and Sustainable Development, 27 to 29 October: Beijing, China

Chapin FS, Knapp CN, Brinkman TJ, Bronen R, Cochran P (2016) Community-empowered adaptation for self-reliance. Curr Opin Environ Sustain 19:67-75. https://doi.org/10.1016/j.cosust.2015. 12.008

Connell J, Coelho S (2018) Planned relocation in Asia and the Pacific. Forced Migr Rev:46-49

Coomes OT, Takasaki Y, Abizaid C, Barham B (2010) Floodplain fisheries as natural insurance for the rural poor in tropical forest environments: evidence from Amazonia. Fish Manag Ecol 17:513-521. https://doi.org/10.1111/j.1365-2400.2010.00750.x

Copestake J (ed) (2008) Wellbeing and development in Peru: local and universal views confronted. Palgrave Macmillan, New York

Copestake J (2011) Well-being in development: comparing global designs with local views in Peru. Eur J Dev Res 23:94-110. https:// doi.org/10.1057/ejdr.2010.45

Correa E (ed) (2011) Preventive resettlement of populations at risk of disaster: experiences from Latin America. World Bank and GFDRR, Washington, D.C.

Costanza R, Fisher B, Ali S, Beer C, Bond L, Boumans R, Danigelis NL, Dickinson J, Elliott C, Farley J (2007) Quality of life: an approach integrating opportunities, human needs, and subjective well-being. Ecol Econ 61:267-276

Diener E, Tay L (2016) New frontiers: societal measures of subjective well-being for input to policy. In: Bruni L (ed) Handbook of research methods and applications in happiness and quality of life. Edward Elgar Publishing, Northhampton, MA, pp 35-52

Dodge R, Daly AP, Huyton J, Sanders LD (2012) The challenge of defining wellbeing. Int J Wellbeing 2:222-235. https://doi.org/10. 5502/ijw.v2i3.4

Drury J, Cocking C (2007) The mass psychology of disasters and emergency evacuations: a research report and implications for practice. University of Sussex, Brighton
Duffy PB, Brando P, Asner GP, Field CB (2015) Projections of future meteorological drought and wet periods in the Amazon. Proc Natl Acad Sci U S A 112:13172-13177. https://doi.org/10.1073/pnas. 1421010112

Farbotko C, Dun O, Thornton F, McNamara KE, McMichael C (2020) Relocation planning must address voluntary immobility. Nat Clim Chang 10:702-704. https://doi.org/10.1038/s41558-020-0829-6

Ferris E, Weerasinghe S (2020) Promoting human security: planned relocation as a protection tool in a time of climate change. J Migr Hum Secur 8:134-149. https://doi.org/10.1177/2331502420909305

French A, Mechler R (2017): Managing El Niño Risks Under Uncertainty in Peru: Learning from the past for a more disaster-resilient future. International Institute for Applied Systems Analysis (IIASA); Soluciones Prácticas; Zurich Insurance Group, Laxenburg

French A, Mechler R, Arestegui M, MacClune K, Cisneros A (2020) Root causes of recurrent catastrophe: the political ecology of El Niño-related disasters in Peru. Int J Disaster Risk Reduction 47: 101539. https://doi.org/10.1016/j.ijdrr.2020.101539

Gasper D (2007) Human well-being: concepts and conceptualizations. In: McGillivray M (ed) Human well-being: concept and measurement. Palgrave Macmillan; in association with the United Nations University-World Institute for Development Economics Research, Basingstoke [England], New York, [Helsinki, Finland], pp 23-64

Georgetown University, UNHCR, IOM (2017) A toolbox: Planning Relocations to Protect People from Disasters and Environmental Change. Georgetown University; United Nations High Commissioner for Refugees (UNHCR); International Organization for Migration (IOM). http://www.unhcr.org/protection/ environment/596f1bb47/planned-relocation-toolbox.html. Accessed 8 August 2018

GFDRR (2010) Disaster Risk Management in Latin America and the Caribbean Region: GFDRR Country Notes Peru. Washington, D.C. Global Facility for Disaster Reduction and Recovery (GFDRR). https://www.gfdrr.org/sites/default/files/publication/ drm-country-note-2010-peru.pdf. Accessed 1 November 2020

Gloor M, Brienen RJW, Galbraith D, Feldpausch TR, Schöngart J, Guyot J-L, Espinoza JC, Lloyd J, Phillips OL (2013) Intensification of the Amazon hydrological cycle over the last two decades. Geophys Res Lett 40:1729-1733. https://doi.org/10.1002/grl.50377

Gough I (ed) (2008) Wellbeing in developing countries: from theory to research. Cambridge Univ. Press, Cambridge

Gulyas J (2015) Hopes and fears - future views of quality of life. In: Glatzer W, Camfield L, Møller V, Rojas M (eds) Global handbook of quality of life: exploration of well-being of nations and continents. Springer Netherlands, Dordrecht, pp 869-894

de Haas, H (2014) Migration theory - Quo Vadis? International Migration Institute Working Papers 100. Oxford. https://www. migrationinstitute.org/publications/wp-100-14. Accessed 2 April 2015

Hino M, Field CB, Mach KJ (2017) Managed retreat as a response to natural hazard risk. Nat Clim Chang 7:364-370. https://doi.org/10. 1038/NCLIMATE3252

Hofmeijer I, Ford JD, Berrang-Ford L, Zavaleta C, Cárcamo C, Llanos E, Carhuaz C, Edge V, Lwasa S, Namanya D (2013) Community vulnerability to the health effects of climate change among indigenous populations in the Peruvian Amazon: a case study from Panaillo and Nuevo Progreso. Mitig Adapt Strateg Glob Chang 18:957-978. https://doi.org/10.1007/s11027-012-9402-6

INEI (2016) Evolución de la pobreza monetaria 2009-2015: Informe Técnico. Instituto Nacional de Estadística e Informática (INEI), Lima

INEI (2018) Censos Nacionales 2017: XII de Población, VII de Vivienday III de Comunidades Indígenas: Sistema de Consulta de Base de Datos a Nivel de Manzana. Instituto Nacional de Estadística e Informática (INEI). https://censos2017.inei.gob.pe/pubinei/index. asp. Accessed 17 December 2020 
Iuchi K (2014) Planning resettlement after disasters. J Am Plan Assoc 80: 413-425. https://doi.org/10.1080/01944363.2014.978353

Kuckartz U, Rädiker S (2019) Analyzing qualitative data with MAXQDA: text, audio, and video. Springer, Cham

Langerwisch F, Rost S, Gerten D, Poulter B, Rammig A, Cramer W (2013) Potential effects of climate change on inundation patterns in the Amazon Basin. Hydrol Earth Syst Sci 17:2247-2262. https://doi.org/10.5194/hess-17-2247-2013

Langill JC (2018) Differential experiences of climate change: local knowledge and perspectives of severe flooding in the Peruvian Amazon. Master's Thesis, University of Toronto

Lavell A, Mansilla, E, Chavez A, Cardona OD, Perez MP (2016) Diagnostic Report: Colombia, Peru \& Mexico (1/4). The Bartlett Development Planning Unit (DPU); Latin American Social Science Faculty (FLACSO). https://www.ucl.ac.uk/bartlett/ development/sites/bartlett/files/diagnostic_flacso_english_spanish v2.pdf. Accessed 4 April 2021

List G (2016) Agriculture and the risk of crop loss in the Amazon River floodplain of Peru. Master's Thesis, McGill University

Marengo JA, Espinoza JC (2016) Extreme seasonal droughts and floods in Amazonia: causes, trends and impacts. Int J Climatol 36:10331050. https://doi.org/10.1002/joc. 4420

Masson-Delmotte V, Pörtner HO, Roberts, D, Skea J, Shukla PR, Pirani A, Moufouma-Okia W, Péan C, Pidcock R, Connors S, Matthews JBR, Chen Y, Zhou X, Gomis MI, Lonnoy E, Maycock T, Tignor, M, Waterfield T (Eds.) (2018): Global Warming of $1.5^{\circ} \mathrm{C}$. An IPCC Special Report on the impacts of global warming of $1.5^{\circ} \mathrm{C}$ above pre-industrial levels and related global greenhouse gas emission pathways, in the context of strengthening the global response to the threat of climate change, sustainable development, and efforts to eradicate poverty. Intergovernmental Panel on Climate Change (IPCC), Geneva

Matthews T, Potts R (2018) Planning for climigration: a framework for effective action. Clim Chang 148:607-621. https://doi.org/10.1007/ s10584-018-2205-3

McMichael C, Katonivualiku M, Powell T (2019) Planned relocation and everyday agency in low-lying coastal villages in Fiji. Geogr J 185: 325-337. https://doi.org/10.1111/geoj.12312

McNulty SL, Guerra Garcia G (2019) Politics and promises: exploring fifteen years of Peru's participatory decentralization reform. Public Organiz Rev 19:45-64. https://doi.org/10.1007/s11115-018-0419-5

MIDIS (2020) MIDISditrito: Reportes Interactivos. Ministerio de Desarrollo e Inclusión Social (MIDIS), Lima. http://sdv.midis.gob. pe/RedInforma/Reporte/Reporte?id=18. Accessed 17 December 2020

MIMP, IOM (2015) Desplazamientos Internos en el Perú. Ministerio de la Mujer y Poblaciones Vulnerables (MIMP); International Organization for Migration (IOM), Lima. http://www.oimperu.org/ sites/default/files/Documentos/Desplazamientos_Internos.pdf. Accessed 1 September 2018

MINAM (2016) El Perú y el Cambio Climático: Tercera Comunicación Nacional del Perú a la Convención Marco de las Naciones Unidas sobre Cambio Climático. Ministerio del Ambiente (MINAM), Lima. http://unfccc.int/resource/docs/natc/pernc3.pdf. Accessed 1 September 2018

Morón EA, Sanborn C (2006) The pitfalls of policymaking in Peru: actors, institutions and rules of the game. IDB Working Paper No. 206. https://doi.org/10.2139/ssrn.1814760

Mortreux C, Safra de Campos R, Adger WN, Ghosh T, Das S, Adams H, Hazra S (2018) Political economy of planned relocation: a model of action and inaction in government responses. Glob Environ Chang 50:123-132. https://doi.org/10.1016/j.gloenvcha.2018.03.008

ND-GAIN (2020) Peru. Notre Dame Global Adaptation Initiative (NDGAIN). https://gain-new.crc.nd.edu/country/peru. Accessed 10 July 2020

Parfit D (1992) Reasons and persons. Clarendon, Oxford
Perry RW, Lindell MK (1997) Principles for managing community relocation as a hazard mitigation measure. J Conting Crisis Manag 5:49 59. https://doi.org/10.1111/1468-5973.00036

Piggott-McKellar AE, Pearson J, McNamara KE, Nunn PD (2019) A livelihood analysis of resettlement outcomes: lessons for climateinduced relocations. AMBIO. 49:1474-1489. https://doi.org/10. 1007/s13280-019-01289-5

Rogers S, Wilmsen B (2019) Towards a critical geography of resettlement. Prog Hum Geogr 97:030913251882465-030913251882275. https://doi.org/10.1177/0309132518824659

Rojas-Medina Y, Vargas Machuca JA, Trujillo OV (2008) Trastorno de estrés agudo y episodio depresivo mayor en víctimas de una inundación en Tingo María: prevalencia y efectos de su desplazamiento a un alberg. Rev Peruana Med Exp Salud Pública 25:66-73

Seebauer S, Winkler C (2020a) Coping strategies and trajectories of life satisfaction among households in a voluntary planned program of relocation from a flood-risk area. Clim Chang 162:2219-2239. https://doi.org/10.1007/s10584-020-02796-1

Seebauer S, Winkler C (2020b) Should I stay or should I go? Factors in household decisions for or against relocation from a flood risk area. Glob Environ Chang 60:102018. https://doi.org/10.1016/j. gloenvcha.2019.102018

de Sherbinin A, Castro M, Cernea MM, Fearnside PM, Krieger G, Lahmani S, Oliver-Smith A, Pankhurst A (2011) Preparing for resettlement associated with climate change. Science 334:456-457

Sherman M, Ford J, Llanos-Cuentas A, Valdivia MJ, Bussalleu A (2015) Vulnerability and adaptive capacity of community food systems in the Peruvian Amazon: a case study from Panaillo. Nat Hazards 77: 2049-2079. https://doi.org/10.1007/s11069-015-1690-1

Sherman M, Ford J, Llanos-Cuentas A, Valdivia MJ (2016) Food system vulnerability amidst the extreme 2010-2011 flooding in the Peruvian Amazon: a case study from the Ucayali region. Food Sec 8:551-570. https://doi.org/10.1007/s12571-016-0583-9

SINAGERD, PCM, SGRD, CENEPRED, INDECI (2014) Plan Nacional de Gestión del Riesgo de Desastres (PLANAGERD) 2014-2021. Sistema Nacional de Gestión del Riesgo de Desastres (SINAGERD), Presidencia del Consejo de Ministros (PCM), Secretaria de Gestión del Riesgo de Desastres (SGRD), Centro Nacional de Estimación, Prevención, y Reducción del Riesgo de Desastres (CENEPRED), Instituto Nacional de Defensa Civil (INDECI), Lima. https://www.preventionweb.net/files/37923 39462planagerd201420215b15d1.pdf. Accessed 10 July 2020

Sipe N, Vella K (2014) Relocating a flood-affected community: good planning or good politics? J Am Plan Assoc 80:400-412. https:// doi.org/10.1080/01944363.2014.976586

Takasaki Y, Barham B, Coomes OT (1999) Risk coping strategies in tropical forests: floods, illnesses, and resource extraction. Environ Dev Econ 9:203-224. https://doi.org/10.1017/ S1355770X03001232

Takasaki Y, Barham B, Coomes OT (2010) Smoothing income against crop flood losses in Amazonia: rain forest or rivers as a safety net? Rev Dev Econ 14:48-63. https://doi.org/10.1111/j.1467-9361.2009. 00538.x

Thaler T, Seebauer S, Schindelegger A (2020) Patience, persistence and pre-signals: policy dynamics of planned relocation in Austria. Glob Environ Chang 63:102122. https://doi.org/10.1016/j.gloenvcha. 2020.102122

Thiery P (2016) Das politische System: Verfassung, Staat und Demokratie. In: Paap I, Schmidt-Welle F (eds) Peru heute: Politik, Wirtschaft, Kultur. Verlag Vervuert, Frankfurt a.M., pp 143-178

Venkateswaran K, MacClune K, Enriquez MF (2017): Learning from El Niño Costero 2017: Opportunities for Building Resilience in Peru. ISET International and the Zurich Flood Resilience Alliance, Boulder 
Warner K, Afifi T (2014) Where the rain falls: evidence from 8 countries on how vulnerable households use migration to manage the risk of rainfall variability and food insecurity. Clim Dev 6:1-17

White SC (2010) Analysing wellbeing: a framework for development practice. Dev Pract 20:158-172. https://doi.org/10.1080/ 09614520903564199

Wilmsen B, Webber M (2015) What can we learn from the practice of development-forced displacement and resettlement for organised resettlements in response to climate change? Geoforum 58:76-85

Witzel A, Reiter H (2012) The problem-centred interview. SAGE Publications Ltd, London

Zavaleta C, Berrang-Ford L, Ford J, Llanos-Cuentas A, Cárcamo C, Ross NA, Lancha G, Sherman M, Harper SL (2018) Multiple non- climatic drivers of food insecurity reinforce climate change maladaptation trajectories among Peruvian Indigenous Shawi in the Amazon. PLoS One 13:e0205714. https://doi.org/10.1371/journal. pone. 0205714

Zulkafli Z, Buytaert W, Manz B, Rosas CV, Willems P, LavadoCasimiro W, Guyot J-L, Santini W (2016) Projected increases in the annual flood pulse of the Western Amazon. Environ Res Lett 11:14013. https://doi.org/10.1088/1748-9326/11/1/014013

Publisher's note Springer Nature remains neutral with regard to jurisdictional claims in published maps and institutional affiliations. 